\title{
核融合炉用超伝導コイル構造材料開発の歩み
}

\author{
島本 進 ${ }^{* 1, \dagger}$, 中嶋 秀夫 ${ }^{* 2}$, 高橋 良和 ${ }^{* 2}$

\section{Evolution of Cryogenic Structural Material Development for Superconducting Coils in Fusion Reactors}

\author{
Susumu SHIMAMOTO ${ }^{* 1}$, Hideo NAKAJIMA ${ }^{* 2}$ and Yoshikazu TAKAHASHI ${ }^{* 2, \uparrow}$
}

\begin{abstract}
Synopsis: Cryogenic structural materials are an essential element to fulfill the performance of superconducting coils for fusion reactors. In this field, there was no specialized steel and mechanical properties data at $4 \mathrm{~K}$ until 30 years ago when the Japan Atomic Energy Agency (JAEA) started the development of the Tokomak fusion reactor. JAEA set a target of mechanical characteristics which could satisfy requirements for the coil structure at $4 \mathrm{~K}$ and equipped evaluation facilities at $4 \mathrm{~K}$ for tensile tests, fatigue tests and so on. At the same time, JAEA initiated collaboration with the steel industries in order to realize new cryogenic structural materials and carried out mechanical evaluation tests at $4 \mathrm{~K}$ on numerous samples which were supplied from the industries. There are two areas: a coil case and a conductor jacket for forced flow conductor. The former requires large forging products and thick hot-rolled plates for the coil case. The latter is influenced by heat treatment at approximately $650{ }^{\circ} \mathrm{C}$ and more than one-hundred hours to produce $\mathrm{Nb}_{3} \mathrm{Sn}$ superconducting material at the final stage. This is a unique issue for the jacket. Finally, both the case and the jacket material for construction of the ITER are now being supplied from the Japanese industries through JAEA. In addition, JAEA contributed to the standardization of these testing methods at $4 \mathrm{~K}$ in Japanese industrial standards (JIS). Furthermore, JAEA supported the establishment of a design code for the structure of superconducting coil for a fusion facility at the Japan Society of Mechanical Engineers (JSME). This paper describes the more than 30-year history of the development of cryogenic structural material.
\end{abstract}

Keywords: cryogenic structural material, superconducting coil, fusion reactor, tensile test, fatigue test

\section{1. はじめに}

磁気閉じ込めのための核融合炉用超伝導コイルは単純な ソレノイド・コイルとは大きく異なる。核融合炉では磁場 が強く、利用する空間も大きいことによりコイルの応力值 は高くなる。そこには数種類のコイルが存在し、これらの 磁場が重畳するので機械設計が重要になり、構造の成否が 鍵となる。炉全体の部品の中で重量を比較しても、超伝導 コイル・システムの構造物が多くを占める。このようなト カマク型の実験炉の製作と建設が現在進行中である。

コイル構造物への力の負荷は、電流と磁場の積として導 体内に発生するローレンツカが積算されて、その表面に加

\footnotetext{
Received November 5, 2012

*1 日本原子力研究開発機構 - 研究嘱託

干 311-0193 茨城県那珂市向山 801-1

Japan Atomic Energy Agency, 801-1 Mukouyama, Naka, Ibaraki

311-0193, Japan

*2 日本原子力研究開発機構 核融合研究開発部門

干311-0193 茨城県那珂市向山 801-1

Japan Atomic Energy Agency, 801-1 Mukouyama, Naka, Ibaraki

311-0193, Japan

† E-mail: takahashi.yoshikazu@jaea.go.jp
}

わる。それは気体あるいは液体による均一な荷重よりは複 雑である。磁場はコイル巻線内に分布しており、構造物の 形状も単純ではない上に、最大応力值は従来の実用機器の レベルをはるかに上回る。これに加えて繰り返し応力も重 畳する。構造物の置かれる状況は断熱真空中の液体へリウ ム温度 $(4 \mathrm{~K})$ であり、通常の生活空間からは推察し難い 別の世界である。

このような条件を満たすための極低温構造材料の開発と その試験手法に着手し 30 年になるので、設計基準につい ても筆を加えて、歩んできた道について解説する。広い分 野の多くの方々に理解していただけるように、初歩的な点 も含めて記述する点をご了承いただきたい。

これまで歩んだ道の多くの成果は、今日建設中の国際 熱核融合実験炉 1) 'ITER'（International Thermonuclear Experimental Reactor) に取り入れられた。ITER の構造材 料の具体的な内容については、別の機会に解説する予定で ある。

文中の「原研」は日本原子力研究所が 2005 年に日本原 子力研究開発機構 (原子力機構) 一組織替えになるまでの 
略称である。コイルや部品の名称等については ITER コ ミュニティーで認知されている用語に準じている。

\section{2. トカマク炉の構成及び構造物内の応力解析と 実測の課題}

トカマク炉を単純化した構成を Fig. 1 に示す。CS (Central Solenoid, 中心ソレノイド) コイルの電流変動に よって、円環状のプラズマを造る。これを TF（Toroidal Field, トロイダル磁場）コイルによる磁場で閉じ込める。 TF コイルの外側にある PF (Poloidal Field, ポロイダル磁 場）コイルによって円環状のプラズマの位置や形状の制御 を行う。ITERの CS コイルの最大磁場は $13.5 \mathrm{~T}$ で、 TF コ イルでは $11.8 \mathrm{~T} 、 \mathrm{PF}$ コイルでは $6.5 \mathrm{~T}$ である。 TF コイル にはコイルが膨らもうとする拡張力に加えて、トカマク炉 の中心回転軸に集まる向心力が働く。これを支持するため、 $\mathrm{TF}$ コイル夫々の $\mathrm{D}$ 型直線部の側面をくさび型にして組み 上げて TF コイル相互で自立できるような構造としている。 さらに、 $\mathrm{TF}$ コイル一つ一つには倒れようとする転倒力も 働くので、D 型の非直線部の両側の上、中、下にコイル間 支持構造物が付けられて互いに支え合うようになっている。 CS コイルは独立して中心軸に収まるが、このコイルに発 生する拡張力は自分自身で支持され、その重力及び上下力 は TF コイルによって支持される。また、PF コイルでも 同様に重力及び上下力は全て TF コイルにより支持される。 このため、TF コイルでは発生する応力值も高く複雑にな り、これを肉厚のコイル容器で支持している。 TF コイル は、人体との類推をすると、核融合炉の脊椎に相当する。

CS、PF、TF の何れのコイルも超臨界圧のヘリウムを流 寸強制冷凍型導体を使うので、超伝導ケーブルは流路とな るステンレス管の中に納められる。ケーブルを包んでいる ので、この管をジャケットと呼んでいる。PF コイルでは

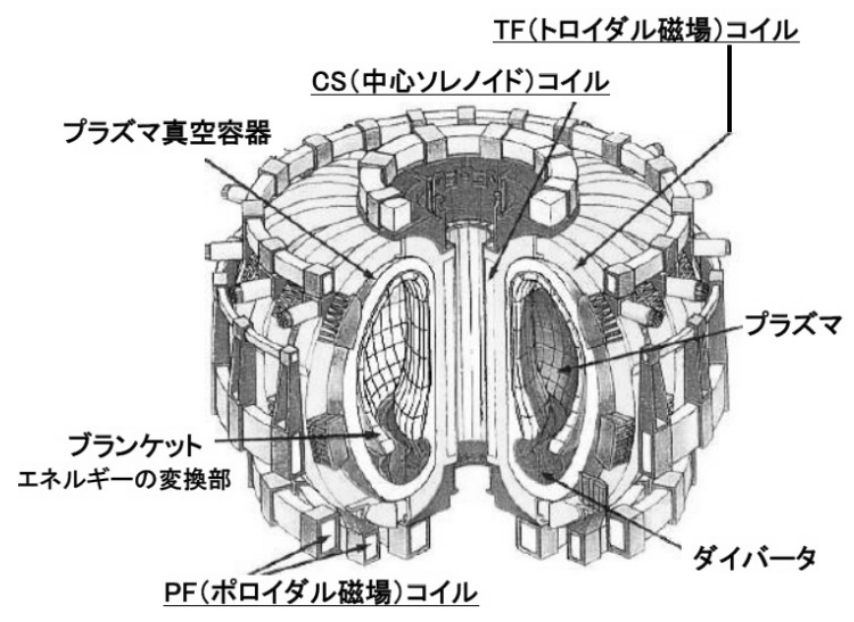

Fig. 1 トカマク核融合炉の概観とその超伝導コイル General view of the Tokomak fusion reactor and superconducting coils.
磁場が低いので超伝導材料として合金である NbTi を使い、 他の二つのコイルでは磁場が高いので金属間化合物である $\mathrm{Nb}_{3} \mathrm{Sn}$ を使用する。 $\mathrm{Nb}_{3} \mathrm{Sn}$ は最終工程において $650^{\circ} \mathrm{C}$ 近辺 で長時間の熱処理により生成されるため、ジャケットには 同じ温度と時間の熱が加わり延性が劣化する。その後にお いても力学的性能が要求されるジャケット材にとってこれ は大きな課題である。一方、PF コイル導体ではこの熱処 理が不要のため、同様の技術課題はない。

$\mathrm{CS}$ コイルと PF コイルは、パルス動作による円環電流 を避けるために、コイル容器を付けていない。従ってこれ らのコイルでは、拡張力を導体自身のジャケットで、他の 力をコイル支持構造物で持たせている。他方、 $\mathrm{TF}$ コイ ル・システムではコイル容器と支持構造物とが大きな円環 をなしており、変動磁場によるここでの円環電流を断つた めに、両者の間には電気絶縁物が挿入されている。

コイルの静的応力解析は、コンピュータによる有限要素 法で行われるが、次のような課題がある。導体内のローレ ンツカがコイル容器に及んでくるまでには、複合的な構造 を横断してくる。つまり、そこは導体や電気絶縁物を含め、 室温から $4 \mathrm{~K}$ までの物性值の差異に加えて、構成材料の間 の接触などデリケートな課題がある。30 年前の開発初期 には浸漬冷凍型導体を採用するコイルが多かったので、導 体間に液体へリウムが浸み込む空隙があり、このためにコ イルの剛性を同定することは難しかった。この欠点を解消 するべく取り入れられた強制冷凍型導体を ITER に適用し た。特にその TF コイルの巻線部にラジアル・プレートと 呼ばれる溝付きのステンレス板を準備して、溝をつけて導 体をはめ込み、このプレートを積層してコイル容器に収納 する手法を取っている。従って、剛性について精度の良い 推定が行えるようになった。応力解析そのものについては、 過去の解析実績やコンピュータ能力の上昇によってかなり 進歩している。加えて、コンピュータにより構造物内での 応力の理論的な等高線が図示され、その分布を直ちに把握 できるようになった。

他方、実測においては本質的課題がある。応力值の直接 測定は周知のように不可能であり、構造物の表面の歪量を 測定することにより算出している。構造物内部の応力值の 測定は更に難しい。このような困難のある実測と解析の比 較の経験を深めることが機械設計には肝要である。今日ま で核融合炉のためのコイルについてこの比較は十分とは言 えないので、ITER の運転・操作においてもこの作業は目 的の一つとなっている。

コイルの繰返し応力に対する疲労評価については、液体 ヘリウム温度において構造材料の疲労特性やき裂伝播特性 の多くのデータが収集されるとともに、破壊力学を用いた 評価も進められるようになっている。実機の動作範囲から 計算される変動応力とこれらのデータとの照合を行い、十 分な裕度を取ることが設計基準で要求されている。 


\section{3. 構造物の破壊を支配する材料パラメータ}

欠陥がない均質な構造物の引張特性を考えると構造材料 の $0.2 \%$ 耐力と引張強さが力学的見地から主要な材料パラ メータである。しかし、実際の構造物では微小な欠陷が存 在することが多い。均等に外部応力が加わってもき裂状の 欠陥がある場合には、その先端のき裂周辺には特異場がで きて、き裂先端での応力は無限大となり、材料力学の範疇 では扱えない事象となる。例えば、体心立方格子を有する 鉄鋼材料は極低温でガラスのように脆くなる性質を持つの で、その内部に欠陥が存在すると外部応力が耐力よりもは るかに低い值で不安定に急速に破壊（脆性破壊）する。こ れを低温脆性と呼ぶ。このため、極低温の構造材料として は低温脆性を示さない面心立方格子のオーステナイト系ス テンレス鋼を用いる。オーステナイト系ステンレス鋼では 低温での脆性破壊は起こさないものの、延性であっても不 安定な破壊を起こす可能性がある。ここでき裂状の欠陥の 存在を仮定して、延性材料でも脆性破壊を起こすと考える ことにより安全側の設計が可能となる。このような破壊現 象を把握するために、外部応力とき裂寸法に関係する次元 である $\mathrm{MPa} \sqrt{\mathrm{m}}$ を持つ応力拡大係数 $\mathrm{K}$ を取り入れ、不安定 破壊を生じる応力拡大係数の限界值を平面ひずみ破壊勒性 值 $\mathrm{K}_{\mathrm{IC}}$ と呼んでいる（以下、単に破壊䩚性值と記す）。ま た、 $\mathrm{K}$ が $\mathrm{K}_{\mathrm{IC}}$ より低くても、構造物に作用する応力が少 しずつ拡大する場合や、応力は一定でも繰り返しによりき 裂が伝播する場合は、欠陥が拡大寸るので $\mathrm{K}$ が増えて $\mathrm{K}_{\mathrm{IC}}$ に近づき、やがて不安定破壊を起こす。これを避けるため

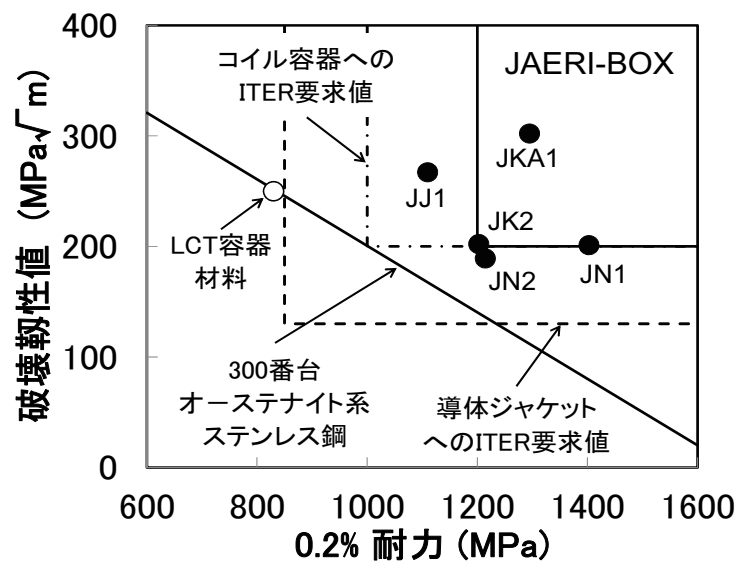

Fig. 2 液体ヘリウム温度 (4K) における 300 番台オース テナイト系ステンレスの耐力と破壊靭性の典型的特性 (JAERI-BOX、ITER のコイル容器構造材料及びジャケッ 卜材への要求值、及び開発材の測定データ)

Typical tensile and fracture characteristics of 300 series austenite stainless steel at $4 \mathrm{~K}$ (development target [called "JAERI-BOX"] based on ITER requirements for coil case and conductor jacket, and measured data of newly developed materials.)
に実際の $\mathrm{K}$ の值が $\mathrm{K}_{\mathrm{IC}}$ の数分の一の值になるように設計 される。 $\mathrm{K}_{\mathrm{IC}}$ は構造材料の性質を示寸固有のパラメータで あり、試験規格によって決められた手法により測定される。 しかし、オーステナイト系ステンレス鋼のように破壊勒性 值が高い材料での測定には、大きな試験片が必要でへリウ ム温度でのその実施には難題が多い。このため、 $\mathrm{K}_{\mathrm{IC}}$ に代 わり、弾塑性破壊䩲性值 $\mathrm{J}_{\mathrm{IC}}$ を求め、この值から $\mathrm{K}_{\mathrm{IC}}$ に換 算する手法をとるのが一般的である。この手法で求められ た $\mathrm{K}_{\mathrm{IC}}$ は $\mathrm{K}_{\mathrm{IC}}(\mathrm{J})$ と表記されることがある。

構造材料の耐力と破壊勒性值は Fig. 2 に示すように一つ の材料で同時に両者の高い值を望めない。材料の耐力を上 げるように材料を改善すると、他方でその破壊勒性值が低 下する。つまり、一つの材料で両者の高い值を満足するの は一般に困難である。しかしこれに甘んじていると核融合 炉のコイルは実現しないので、これを凌駕することが開発 の一つの目的であった。耐力と破壊勒性については材料開 発の視点からは能動的に探究が可能なのに対して、次に述 べる疲労特性とき裂伝播速度は材料の従属的なパラメータ であり、当初からこれをターゲットにする開発はできない。 疲労破壊は繰り返しの外力が加わることによって生ずる 破壊で、繰り返し数が $10^{4}$ レベルまでを低サイクル疲労と 呼びその上を高サイクル疲労と呼んでいる。材料に繰返し 力を加えた時の疲労特性は、縦軸に応力の振幅值を取り、 横軸に破壊した時の繰返し回数を取ったグラフで表記する。 このグラフを疲労曲線（応力一破断回数曲線、S-N 曲線） と呼んでおり、実際の機器の作動範囲はこの曲線より十分 低い場所で設計する。

き裂伝播速度は繰返し応力が加わった時のき裂長さの進 展具合を示すものである。き裂の長さは、荷重と試料に付 けたクリップ・ゲージで測定した開口変位の関係を求め、 直線部分の傾きの逆数（コンプライアンス）から、き裂長 さを計算することにより求める。き裂伝播速度は、き裂の 進展の長さを繰り返し数でプロットした曲線を作成し、こ の曲線の微分值として決定される。また、き裂伝播速度は 作用した応力の振幅から計算される応力拡大係数の範囲と 両対数グラフ上で直線となることが経験的に分かっており、 これを Paris 則と呼んでいる。構造材料のき裂伝播速度と 応力拡大係数の範囲との関係を示すグラフよりこの経験則 の係数を求めて、設計では使用範囲の適性を検討する。

Table 1 材料の 4 つのパラメータの識別：静的な荷重と 繰返し荷重、欠陥の存在の有無

Four parameters arranged to characterize the mechanical properties of materials on static and cyclic loads

\begin{tabular}{|c|c|c|}
\hline 設計手法 & 静的な荷重 & 繰返し荷重 \\
\hline $\begin{array}{c}\text { 欠陥を仮定しない } \\
\text { 設計 }\end{array}$ & $\begin{array}{c}0.2 \% \text { 耐力, } \\
\text { 引張強さ }\end{array}$ & 疲労 $(\mathrm{S}-\mathrm{N})$ 特性 \\
\hline $\begin{array}{c}\text { 欠陥を仮定した } \\
\text { 設計 }\end{array}$ & $\begin{array}{c}\text { 破壊靭性值, } \\
\mathrm{K}_{\mathrm{IC}}\end{array}$ & $\begin{array}{c}\text { き裂伝播速度, } \\
\mathrm{da} / \mathrm{dN}\end{array}$ \\
\hline
\end{tabular}


以上に記述した 4 つのパラメータをここで整理してみる。 一方向の力による強度の測定の場合と繰返しの力が加わる 疲労特性の測定の場合は、初期欠陷を考えていないので材 料力学の範囲である。これに対して初期欠陥の考えを取り 入れその拡大による破壊を考える破壊力学の領域では、破 壊勒性值とき裂伝播速度を取り入れ設計に適用する。破壊 勒性值では一方向の負荷を考え、き裂伝播速度では繰返し 力の負荷を考えている。これらを整理して Table 1 として 表示すると、材料評価の試験と設計を考える時に混乱を避 けられる。

上記以外の材料の力学的パラメータの一つとしてシャル ピー衝撃試験の吸収エネルギー值がある。これは或る重さ のハンマーを持ち上げておきこれを落下させ試験材にぶつ け、材料が破壊するまでに吸収するエネルギー值を見るも のである。考え方としては破壊勒性值に対応するものであ るが物理量の次元としては全く異なる。この吸収エネル ギ一值の測定は比較的簡単で、利用されている場合も多い。 例えば同じ材料で経年変化を見るには非常に有力な手段で ある。この例として、原子炉内の構成材の照射脆化による 勒性劣化の観測が挙げられる。他に、材料の開発段階にお

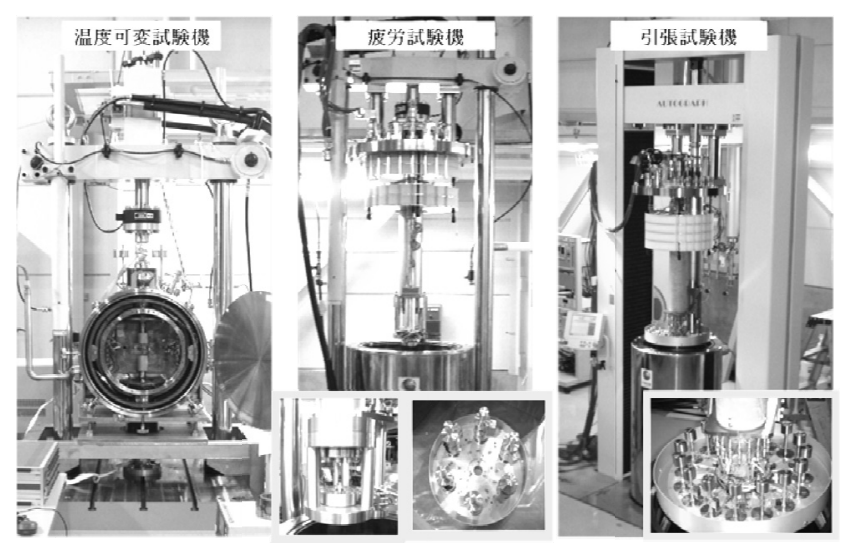

Fig. 3 原子力機構に設置の極低温材料試験装置 View of three cryogenic test facilities for structural materials installed in JAEA.
いて荒い選別にも適している。しかし、ヘリウム温度での シャルピー衝撃試験の吸収エネルギー值については、後に 記すように条件をきちんと設定しにくいので材料の絶対的 評価には向いていないという結論に至った。

\section{4. 材料評価の設備}

3.で説明した材料の機械的性質を $4 \mathrm{~K}$ で測定するために、 Table 2 に示す 3 台の試験機で構成される極低温構造材料 試験装置が原子力機構に整備されている。その外観を Fig. 3 に示す。引張試験機は、構造材料の引張特性（ $0.2 \%$ 而力、 引張強さ、延び、絞り）を測定するための装置であり、機 械ねじ駆動型の試験機に真空断熱層を持つへリウム容器 (デュワー）と引張治具を取り付けたものである。疲労試 験機は、構造材料の破壊勒性值（主として弾塑性破壊勒性 值 $\mathrm{J}_{\mathrm{IC}}$ )、疲労特性（S-N 曲線）、疲労き裂進展速度 $(\mathrm{da} / \mathrm{dN})$ を測定するための装置であり、これは油圧サーボ型の試験 機に、デュワーと疲労治具を取り付けた構造である。液体 ヘリウムは貴重で、極低温の状態を効率的に利用する必要 があるので、1 回の冷却で複数本の試験ができるように工 夫されている。つまり、ターレット・ディスクと呼ぶ回転 円盤に複数本の試験片を取り付けて、1 本の試験終了後に 液体ヘリウム中でターレット・ディスクを回転させて次の 試験片に移動する。引張試験では最大 16 本、破壊勒性あ るいは疲労き裂進展試験では最大 6 本の試験片の取り付け が可能である。さらに、室温から約 $12 \mathrm{~K}$ の間で温度を可 変できる引張試験機がある。この試験機は二つの真空層を 有し、内側の真空層に液体へリウムで冷却した銅を置き、 加えて、この真空層に充填したへリウム・ガスの対流によ り試験片を冷却する。試験片の両端の治具部分には、温度 計が取り付けてあり、この温度計をモニターしながら、液 体ヘリウムの流量を調整することで、試験片の温度を制御 し、所定の温度での試験を実施する。

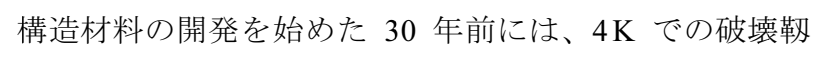
性試験はその技術も普及しておらず、試験規格もなかった。 このため、破壊勒性試験とは次元が異なるが、予備試験と

Table 2 原子力機構に設置されている極低温構造材料試験装置の性能 Characteristics of cryogenic test facilities for structural materials installed in JAEA

\begin{tabular}{|c|c|c|c|c|}
\hline & 引張試験機 & \multicolumn{2}{|c|}{ 疲労試験機 } & 温度可変引張試験機 \\
\hline 最大荷重（kN） & 100 & 100 & \pm 50 & 100 \\
\hline 試験機形式 & 機械ねじ駆動型 & \multicolumn{2}{|c|}{ 電気油圧サーボ駆動型 } & 電気油圧サーボ駆動型 \\
\hline $\begin{array}{l}\text { 適用試験及び } \\
\text { 試験規格 }\end{array}$ & $\begin{array}{c}\text { 引張試験 } \\
\text { JIS Z } 2277\end{array}$ & $\begin{array}{c}\text { 弾塑性破壊靭性試験 } \\
\text { JIS Z } 2284\end{array}$ & $\begin{array}{c}\text { 引張圧縮疲労試験 } \\
\text { JIS Z } 2283 \\
\text { き裂進展速特性試験 } \\
\text { ASTME } 647 \text { 準拠, } 10 \mathrm{~Hz}\end{array}$ & $\begin{array}{c}\text { 引張試験 } \\
\text { JIS Z } 2277 \text { 準拠 }\end{array}$ \\
\hline 試験温度 & $\begin{array}{l}\text { 液体へリウム中 }(4 \mathrm{~K}) \\
\text { 液体窒素中 }(77 \mathrm{~K}) \\
\text { 大気中 (室温) }\end{array}$ & \multicolumn{2}{|c|}{$\begin{array}{l}\text { 液体へリウム中 }(4 \mathrm{~K}) \\
\text { 液体窒素中 }(77 \mathrm{~K}) \\
\text { 大気中 (室温) }\end{array}$} & $\begin{array}{c}\text { ヘリウム・ガス中 } \\
(12 \mathrm{~K} \text { ～室温 })\end{array}$ \\
\hline $\begin{array}{l}\text { 極低温治具の } \\
\text { 特徵 }\end{array}$ & $\begin{array}{l}\text { ターレット・ディスクを } \\
\text { 装備 : 試験片 } 16 \text { 本まで }\end{array}$ & 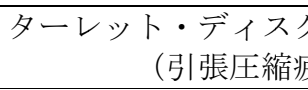 & $\begin{array}{l}\text { 装備：試験片 } 6 \text { 本まで } \\
\text { 試験を除く) }\end{array}$ & $\begin{array}{l}\text { ヘリウム・ガス雰囲気 } \\
\text { で中間温度の試験可能 }\end{array}$ \\
\hline
\end{tabular}


してシャルピー衝撃試験を行っていた。4K でのシャル ピー衝撃試験方法としては、真空断熱層を持つ小型ガラス 容器に試験片を入れ、ここに液体へリウムを入れ、試験片 を液体へリウムに漬けた状態のまま試験を行う方法と、試 験片を発砲スチロールで巻き、液体ヘリウムを発砲スチ ロールの中に流し、温度が安定する一定時間経過後に試験 する方法がある。前者は、試験前の温度は $4 \mathrm{~K}$ に保持され るが試験片が浮いた状態で試験されるため、衝撃值の補正 が必要である。これに対して、後者では試験片は液体へリ ウムに漬かっていないが、衝撃值の補正の必要はない。ど ちらの方法でも試験前の温度は $4 \mathrm{~K}$ と仮に見なしても、衝 撃エネルギーの吸収により比熱が小さくなっている試験片 の温度は上昇するために、破壊瞬間における温度の定義は 難しい。従って、低温におけるシャルピー衝撃試験の温度 範囲としては、比熱が大きい室温から液体窒素の $77 \mathrm{~K}$ ま でという見方が固まった。この見解は後に記すように国際 的な議論でも認知された。

\section{5. 達成目標値の設定及び鉄鋼企業との共同開発}

構造材料の開発を始めた当時は、極低温試験装置は普及 しておらず、 $4 \mathrm{~K}$ での強度評価を実施できる機関は限られ ており、鉄鋼メーカー単独での材料開発は難しい状況に あった。さらに、極低温用構造材料の開発では、 $4 \mathrm{~K}$ で幾 つかの物理量につき多数の試料の評価が必要不可欠である が、設備と測定技術を考慮すると、代表的な測定機関が統 一的に評価することが望まれた。このような状況の下、原 研が $4 \mathrm{~K}$ でのすべての評価を担当し、素材開発は鉄鋼メー カーが担当する戦略を構築した。さらに、複数の鉄鋼メー カーとの共同研究を進めることで、メーカー間の競争を促 進し、潜在的な能力を引き出すことにより、効率的で、か

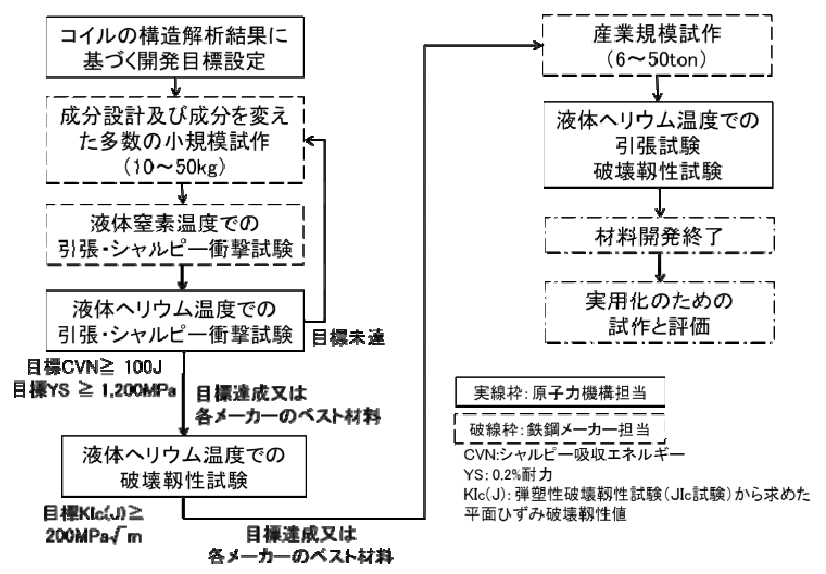

Fig. 4 極低温構造材料の開発過程：原子力機構と鉄鋼 メーカの役目分担

Development procedure of cryogenic structural materials and role sharing between JAEA and steel industries.
つ、実質的な開発を進めることが可能となる。このため、

Fig. 4 に示すプロセスで開発を進めた。

原研は、原研の開発提案に賛同した鉄鋼メーカー4 社 〔(株)日本製鋼所、（株）神戸製鋼所、新日本製鐵(株）（現 新日鐵住金(株))）、及び川崎製鉄(株）（現 JFE スティー ル(株) ) と本戦略に基づき、共同研究を結び開発を進め た。原研が 1982 年に神戸で開催された国際低温工学・低 温材料会議 (CEC9-ICMC) で、 $4 \mathrm{~K}$ でのコイル容器の開発 目標（耐力 $1,200 \mathrm{MPa}$ 以上、破壊勒性值 $200 \mathrm{MPa} \sqrt{\mathrm{m}}$ 以上) を初めて国際的に発表 ${ }^{2)} し た$ 時は、開発目標の高さに米国 から開発の成功を危ぶまれた。しかし、この目標領域は、 原研の英文略称 'JAERI’ を用いて JAERI-BOX (Fig. 2 参照) と国際的に名づけられて、その後の極低温構造材料開発の 標準的な目標として広く使用された。開発項目と条件は、 以下に示すとおりであるが、設定根拠に関しては、文献 ${ }^{3)}$ を参照されたい。

(1) $0.2 \%$ 耐力 $\geqq 1,200 \mathrm{MPa}(4.2 \mathrm{~K})$

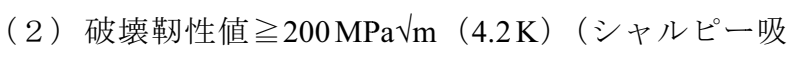
収エネルギーミ100 J $(4.2 \mathrm{~K}))$

(3) 疲労特性:ステンレス 316 と同等以上 $(4.2 \mathrm{~K})$

（4）磁性: 磁性材料でも可（非磁性材料が望ましい）

（5）耐食性：耐錆性を有すること

（6）その他：溶接性、切削性、加工性等が良好である こと

この開発において、100 鋼種以上の素材を試作・試験し 選別し、その後工業的規模で製作・評価した結果、各社を 代表する 5 鋼種の材料（JJ1、JK2、JN1、JN2、JKA1）が 将来の候補となった ${ }^{4)}$ 。これらの材料は、極低温での窒素 の固溶強化による強度上昇を図り、ヘリウム温度の強度を 室温の 3 倍程度まで高めたオーステナイト系ステンレス鋼 である。窒素の固溶度を増すためクロムを多く含有する鋼 種（JN1、JKA1）、マンガンを多く含有する鋼種（JJ1、 JK2、JN2）に大別される。当時の良好な経済情勢もある が、原研が主導して次のプロジェクトを明確にすることに より、鉄鋼メーカーの協力を得ることで、日本独自の極低 温構造材料の開発を成功裡に進めることができた。ジャ ケット材の開発については、この容器材開発に引き続いて 行われた。

\section{6. 開発の初期から実験炉へ}

\section{1 コイル容器としての構造材料}

1977 年に原研が参加した国際協力の LCT 計画（Large Coil Task） ${ }^{5)}$ は超伝導の TF コイル開発の第一歩であった。 最大磁場は $8 \mathrm{~T}$ であったが、これによって核融合炉用超伝 導コイルの開発が世界で同時に着手された。このプロジェ クトは数多くの開発項目に刺激を与え、コイル容器とジャ 
ケットの構造材料への第一歩もその一つである。同じ時期 に米国独自の計画としてミラー型核融合装置 MFTF の超 伝導コイルの製作が行われた。複雑な形状のコイルの構造 材料について評価試験が行われ、LCT 計画との意見交換 が行われる等、多くの足跡を残したが、コイルの試運転直 後にプロジェクトが閉鎖された。そのために後の進展がな かったことは残念である。

LCT 計画の発足当初では、液体へリウム温度における 鉄鋼材料の力学的特性のデータは世界で殆どなかった。

LCT 計画の基本仕様ではコイル容器材はステンレス 304 あるいは316と指定されていた。この目的のために、米国 が $4 \mathrm{~K}$ での 304 の耐力と破壊勒性值の特性をグラフに示し、 構造物の性能の重要性を指摘した。日本国内の標準的なス テンレス鋼についてもこの温度におけるデータが皆無で あったので、原研は早々に評価試験装置を準備して 304 の 評価を開始した。そして日本の LCT コイルに採用する鋼 材を鉄鋼企業と協力して開発した。その結果、窒素の含有 率 $0.14 \%$ の $304 \mathrm{LN}$ が $4 \mathrm{~K}$ で、耐力 $830 \mathrm{MPa}$ で破壊勒性值 $250 \mathrm{MPa} \sqrt{\mathrm{m}}$ を満足することがわかった。コイル容器に加 わる最大応力值は計算では $650 \mathrm{MPa}$ である。この材料の 鍛造品を使用した日本のコイルは、米国における LCT コ イルのあらゆる実験条件を満たすことができた。このプロ ジェクトの終りに近づくころ、原研では次のステップであ

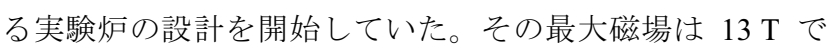
$\mathrm{TF}$ コイルの利用空間も大きく、超伝導材料も構造材料も 大幅な技術開発なしにはその実現が不可能であることが明 白であった。そこで $\mathrm{TF}$ コイル容器と支持構造材料のため に、先に記した JAERI-BOX を目標にメーカーとの共同開 発に拍車をかけた。その結果として、海外から到達不可能 といわれた JAERI-BOX の領域に入る鋼材の利用が可能に なった。その中から製作性、加工性、溶接性、コストの条 件を鑑みて今日の ITER の TF コイル容器に適用するもの が選ばれている。それらは JJ 1 及び 316LN である。ITER の $\mathrm{TF}$ コイルは形状も大きく容器に応力分布がある。この 分布に対応する区分けを行い、コストと加工性からこの区 分けに対応した鋼種の使用が決まっている。これまでの実 績に従って、コイル容器の鋼材は全量を日本が製造する ITER の製作協定になっている。

\section{2 強制冷凍型導体のジャケットとしての構造材料}

ジャケットの肉厚と形状という点から ITER 実機の TF 導体と CS 導体を見ると、異なった点がある。 TF 導体の 外形は円で、先に記したようにラジアル・プレートの溝の 中に一本ずつはめ込む。このプレートによって巻線部の剛 性を上げた分、 TF 導体ジャケットは薄肉で間に合う。他 方、CS コイルはパルス動作なので、渦電流を回避するた めこのようなプレートの適用は不可能であり、CS 導体に は外形が四角の肉厚ジャケットを用いざるを得ない。TF ジャケットでは薄肉のため材料の強度に注視すれば十分で
ある。CS ジャケットは厚肉であり、破壊様式を考慮する と破壊勒性值の考慮が必要となる。このようにこの二つの 鋼材の設計における注目点は同じではない。両者の ITER 以前の開発は各々のプロジェクトの経緯によって次のよう に別個に進んだ。

$\mathrm{TF}$ 導体のジャケット材料開発の歩みは次の様である。 1970 年代末に米国 LCT コイルの一つは超伝導材料として $\mathrm{Nb}_{3} \mathrm{Sn}$ を使用して、強制冷凍型導体を採用した。早々に直 面したのはジャケット材料が受ける本来目的としない熱処 理条件である。米国はこれに耐えるために、このジャッケ ト材料に高マンガン系の Nitronic40を採用したが、熱処理 による勒性劣化による困難が生じ、材料を二転三転させた 後にニッケル $30 \%$ JBK75 を採用した。この米国の LCT コイルは当初の目的を達成できたが、強制冷凍型導体での $\mathrm{Nb}_{3} \mathrm{Sn}$ とジャケット材料の難しさを提示した。当時日本の LCT コイルでは、NbTi による浸漬冷凍型導体を採用した ので、この問題には直面しなかった。その後に核融合炉の コイルでは $\mathrm{Nb}_{3} \mathrm{Sn}$ と強制冷凍型導体を全面的に取り入れ ることになった。その状況で ITER 工学 R\&D の協定の下、 欧州が TF モデル・コイル 3)を担当した。当初そのジャ ケット材料としてニッケルを 40\%含むインコロイ 908 を 考えていたが、この材料には課題が多かった。このため他 のジャケット材料の提案や試作があった。その中には純チ タンも見られたが、強度と製作上の問題等で実機には適用 にならなかった。その後にステンレス 316LN の炭素と窒 素の適切な含有量によって熱処理に耐えられることも分 かったので、 $\mathrm{TF}$ モデル・コイル導体のジャケット材料を 変更して $316 \mathrm{LN}$ を使用し目的を達成した。更にその後、 日本における研究成果も波及して、ITER 実機の TF ジャ ケット材料には $316 \mathrm{LN}$ を使用することが決まっている。

$\mathrm{CS}$ 導体のジャケット材料の開発は上記と異なった道を 歩んだ。LCT 計画の終り頃に原研での強制冷凍型 $\mathrm{Nb}_{3} \mathrm{Sn}$ 導 体を用いたパルス運転コイルの開発は、CS コイルの先行 した開発を目的として国内プロジェクトとして立ち上がっ た。1986 年に開始したこのプロジェクトは DPC 計画 ${ }^{6)}$ と 呼ばれ、直径 $1 \mathrm{~m}$ の空間にパルスで $8 \mathrm{~T}$ を発生することが 最終目標であった。それまでに鉄鋼メーカーと共同開発し た幾つかの新しい構造材料をこのプロジェクトの構造物と して積極的に取り入れた。その中で代表的なものがジャ ケット材料の $\mathrm{JK} 1^{7)}$ であり、大型導体の熱処理条件下でもそ の機械特性を十分に満足した。この鋼材による導体で $6.7 \mathrm{~T}$ まで 1 秒で立ち上げることを達成したのは 1991 年であ る。次の原研のステップは ITER 工学 R\&D 協定として実施 した CS モデル・コイルである。これは直径 $2 \mathrm{~m}$ の空間に $13 \mathrm{~T}$ まで 6 秒で立ち上げるのが達成目標であった。CS モ デル・コイルでは、米国提案によるステンレスの締付けボ ルトとジャケット材料との熱収縮率の差によってコイルを 締め付けるアイデアを受け入れて、米国製のインコロイ 
908 を採用した。この材料では熱処理によるひび割れが生 じ大きな問題となったが、知恵と工夫 ${ }^{8)}$ とよりこれを克服 して 2000 年に CS モデル・コイルのパルス動作で $13 \mathrm{~T}$ の 達成に成功 ${ }^{9}$ した。しかし、インコロイ 908 は素材費が高 く取扱いがデリケートなので、結局 ITER 実機の CS 導体 ジャケットには不適当と判断された。これは欧州における $\mathrm{TF}$ モデル・コイルのジャケット材の変更と符号する。他 方、日本が先に DPC 計画用に開発した JK1 は熱収縮率の 点から不適当であった。一方、原研が鉄鋼メーカーと共同 で開発した JK2 $2^{4)}$ が、インコロイと類似の熱収縮率と疲労進 展特性を有することが判明した。これを受けて、熱処理後 の勒性劣化を防止するため少量のボロンを添加するととも に、炭素の低減を図った改良型 JK2 として、JK2LB を開発 した ${ }^{10)}$ この JK2LB はジャケット材料として最適である ことから、ITER の仕様に合わせた窒素含有量の最適化を 実施し、ITER 実機の CS 導体ジャケット材料として決定し た。

\section{7. 液体ヘリウム温度における材料試験の標準化}

材料試験の標準化は、試験片の幾何学的条件の統一と荷 重の物理的条件の統一にある。この統一がないと、材料 個々の比較が不可能である。この作業は次に記すような国 際的な協調によって大いに進歩した。

米国エネルギー省は核融合炉に向けて日本の極低温構造 材料の開発とその評価活動に注目して、二国間でのワーク ショップと人員派遣協定を提案してきた。標準化の前段 としては、1984 年から 1994 年の間に数回行われた日米 核融合ワークショップ「極低温構造材料と設計基準

(Workshop on Low Temperature Structural Materials and Standards）」による活動がある。その間に米国 NBS（現 NIST）の研究者が原研に長期滞在するとともに、日米の 研究機関、大学を中心に液体へリウム温度での引張試験、 及び破壊靭性試験のラウンド・ロビン試験を実施した ${ }^{11}$ 。 ラウンド・ロビンとは、同じ材料を用いて、各々の装置、 試験条件で試験を行い、装置、試験条件による差異の評価 を行うことである。つまり、それぞれで開発した材料を交 換して測定結果を議論する有意義な作業であった。その頃、 米国は $4 \mathrm{~K}$ での引張試験方法を ASTM (American Standard of Testing Material）として規格化する準備を進めていた。 これ見て原研は当時の工業技術院に連絡を取り、この活動 で得られた標準的な試験方法を国内の JIS 規格とするよう 働きかけた。原研の職員がこの規格を策定する委員会のメ ンバーに加わり、この結果として、その $4 \mathrm{~K}$ での引張試 験規格が発行された ${ }^{12)}$ 。米国では同じ頃に、その規格が ASTM E 1450 として発行された。この引張試験の標準試 験片は、当時原研が使用していた直径 $7 \mathrm{~mm}$ に対応する寸 法となっている。ASTM でもこのサイズを標準試験片と して採用しており、ASTM の室温規格にもない試験片が
採用されたことは、日本が先導していたことを示している。 さらに、原研、MIT、NBS の三者の協力で液体へリウム 温度におけるシャルピー衝撃試験についても研究調査し、 液体窒素温度（77 K）が適用限界であることを示したのも この活動の一環である ${ }^{13)}$

標準化の後段である 1994 年から 1998 年の国内活動で は、破壊勒性試験方法について、日米協力で作成した規格 案を基に日本独自の活動として JIS 規格化を進めた。この 活動により、破壊勒性試験方法が規格化された ${ }^{14)}$ 。さら に、この活動では疲労試験の規格化も実施された ${ }^{15)}$ 。この 二つの規格に対応する ASTM 規格は今現在見当たらない。 その他、ドイツのカールスルーエ研究所とも同じ材料を用 いた試験による相互確認を行い、標準化を深める活動を 行った。

\section{8. 設計基準の設定}

超伝導コイルの構造設計で使用する設計基準は、構造材 料の開発と並んで非常に重要である。特に、新しく開発し た高強度材料では、 $4 \mathrm{~K}$ での降伏比（0.2\%而力と引張強さ の比）が大きくなり、従来の設計基準では合理的な設計が できない。このため、原研は独自の基準として、0.2\%耐 力の $2 / 3$ と引張強さの $1 / 2$ の低い值で許容応力を設定する ことが、合理的な超伝導コイルの設計に結びつくことを提 案 ${ }^{16)}$ するとともに、DPC 計画及び CS モデル・コイル計 画では、この基準によりコイルを設計製作することで実績 を整えた。その後、日本機械学会に設置された核融合専門 委員会で、日本が調達する ITER 超伝導コイルの構造物に ついての規格を策定することが 2006 年に決定され、設計 基準に関しても協議された。超伝導コイルは、塑性域では 超伝導状態を維持できず、主荷重の電磁力も働かない等、 引張強さに対する安全係数を通常の圧力容器より下げても 十分な安全を確保できることから、従来原研が主張してき た $0.2 \%$ 耐力の $2 / 3$ と引張強さの $1 / 2$ の低い值で許容応力 を求めることが妥当と判断され、規格として規定された。

この規格は、機械学会から 2008 年に和文として発行さ

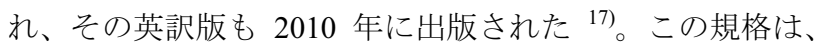
米国との共同開発の経緯から、ASME コードを多数引用し ているが、材料規程は日本独自の考えに基づくもので世界 に類を見ない先進的な規程となっており、原子力機構が長 年にわたって蓄積した材料開発、評価分野での経験が活か されている。

\section{9. おわりに}

核融合実験炉用超伝導コイルの構造材料の開発がたどっ てきた歩みの全貌を述べた。13 T の磁場が全く手中に無 い時代から、核融合実験炉を実現させるためには、超伝導 材料の性能向上のみでなく構造材料の開発にも同様に力を 入れてきた。材料として、溶接材料と溶接性、鍛造品と圧 
延品、加工性等も選別の選定の条件であり実際の作業も行 われている。本文では煩雑になるので記述を控えた。

鉄鋼は重厚長大な分野と見られているが、その中にあっ てもここに記した様な未踏分野が存在しており、その開発 の成果を示すことができる。経済や産業とは別個に、未踏 分野に挑戦することも一つの文化として見ることは重要と 思う。目標值の設定と評価試験を行い、メーカーとの材料 開発を進めつつ、試験規格を確立し、設計基準も決めてゆ く手法を取った。ここに記した手法が今後の類似のプロ ジェクトの参考になれば幸甚に思う。

継続して開発してきた 30 年は途中に紆余曲折があった が、今日の実験炉の様子をみると有意義であったことが分 かる。その間に日本の技術的見解と開発が指導的立場に なった。組織は原研から原子力機構へと移行したが、夫々 の時代にご指導、ご鞭撻いただいた歴代の上司に心から御 礼いたします。協力して作業を行ってきたスタッフを代表 して本文を記述しましたが、その努力の結果で今日に至っ たことを改めて記します。鋼材の開発では共同研究協定を 結んだ鉄鋼メーカーには、原研による極低温でのデータと 議論に基づき、直ちに次のステップに進んでいただきまし た。このような協力のもとに今日の成果があり、共同研究 を進めたこれら複数の鉄鋼メーカーに感謝いたします。

本文をまとめるに当たって、原子力機構の森正博核融合 研究開発部門長、多田栄介副部門長にご指導いただきまし た。ここに感謝の意を表します。

\section{参 考 文 献}

1) ITER 工学設計、プラズマ・核融合学会誌、第 78 巻増刊 (2002)

2) K. Yoshida, et al.: "Development of cryogenic structural materials for tokamak reactor", Austenitic Steels at Low Temperatures, Plenum Press, New York (1983) 29-39

3) 中嶋秀夫、島本 進 :「核融合実験炉用超電導コイル構造材 料の開発」、日本原子力学会誌 27 (1985) 9-14

4) H. Nakajima, K. Yoshida and S. Shimamoto: "Development of new cryogenic steels for the superconducting magnets of the fusion experimental reactor", ISIJ International 30 (1990) 567578

5) 島本 進：「超電導トロイダル・コイル開発の国際協力 “LCT 計画”の展開と成果」、低温工学 24（1989） 135

6)辻 博史、他：「核融合装置用超電導ポロイダル・コイルの 開発」、日本原子力学会誌 30 (1988) 851

7) H. Nakajima, et al.: "Tensile properties of new cryogenic steels as conduit materials of forced flow superconductors at $4 \mathrm{~K}$ ", Advances in Cryogenic Engineering Materials 34 (1988) 173181

8) T. Kato, et al.: "Avoidance method study for SAFBO cracking during heat treatment of a ITER CS model coil conductor using Incoloy 908 jacket," Advances in Cryogenic Engineering Materials 44 (1998) 9-15

9) 特集号「ITER-CS モデル・コイルと CS インサート・コイ ルの実験結果」、低温工学 36 (No.6) (2001) \{解説 2、論文 9\}

10) H. Nakajima, K. Hamada, K. Takano, K. Okuno and N. Fujitsuna: "Development of low carbon and boron added 22Mn - 13Cr - 9Ni - 1Mo - 0.24N steel (JK2LB) for jacket which undergoes Nb3Sn heat treatment”, IEEE Trans. Appl. Supercond. 14 (2004) 11451148

11) H. Nakajima, et al.: "Interlaboratory tension and fracture toughness test results for CSUS-JN1 (Fe-25Cr-15Ni-0.35N) austenitic stainless steel at $4 \mathrm{~K}$ ", Advances in Cryogenic Engineering Materials 36 (1990) 1069-1076

12) JIS Z 2277 (1990) 液体へリウム中における金属材料の引張 試験方法

13) H. Nakajima, et al.: "The chary impact test as an evaluation of 4 $\mathrm{K}$ fracture toughness", Advances in Cryogenic Engineering (Materials) 38 (1992) 207-215

14) JIS Z 2284 (1998) 液体へリウム中における金属材料の弾塑 性破壊じん (靭) 性試験方法

15) JIS Z 2283 (1998) 液体へリウム中における金属材料の低サ イクル疲労試験方法

16) 中嶋秀夫、吉田 清、島本 進 :「極低温構造材料の開発と 構造設計基準 一核融合炉用超電導コイルを中心としてー」、 低温工学 21 (1986) 197-204

17) 日本機械学会 : 核融合設備規格 超伝導マグネット構造規 格（2008 年版）

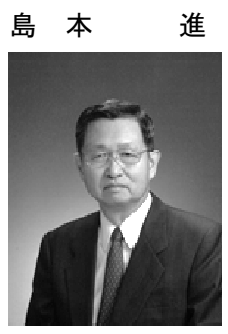

1938 年生。1961 年東北大学卒業。電気試 験所、フランス・サクレー原子カセンター、 日本原子力研究所核融合那珂研究所で超伝 導・核融合炉技術の開発に従事。1997 年東 北大学教授。その後、日本原子力研究開発機 構研究嘱託、成蹊大学理工学部講師。科学技 術庁長官賞等受賞、電気学会会員。

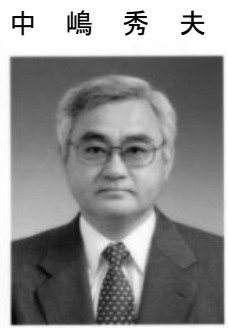

1956 年 1 月生。1981 年日本原子力研究所 に入所。入所以来、大型超伝導コイル、極低 温用構造材料、及び極低温材料試験 - 評価技 術の研究開発に従事。現在、日本原子力研究 開発機構 核融合研究開発部門で、ITER TF コイル構造物の調達、規格・基準の整備等に 従事。低温工学・超電導学会、日本機械学 会、日本鉄鋼協会、日本保全学会会員。

高 橋 良 和

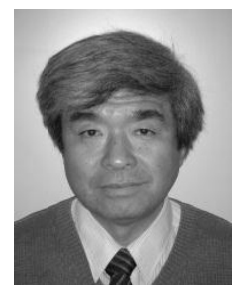

1952 年生。1980 年日本原子力研究所に入 所。大型超伝導コイル、超伝導導体及びそれ らの性能試験・評価の研究開発に従事。現 在、日本原子力研究開発機構（嘱託）で、 ITER 超伝導導体の調達に従事。低温工学・ 超電導学会、電気学会、物理学会、プラズマ 核融合学会会員。理学博士。 